\title{
INTERNATIONAL HUMAN RightS IN Czech Legal Education ${ }^{1}$
}

\author{
Petr Kilian; Ivo Pospíšil; Hubert Smekal \\ Masaryk University, Faculty of Law, Brno, Czech Republic \\ 254699@mail.muni.cz; fandhir@mail.muni. \\ cz; hubert.smekal@law.muni.cz
}

KILIAN, Petr; POSPÍŠIL, Ivo; SMEKAL, Hubert. International Human Rights in Czech Legal Education. International and Comparative Law Review, 2016, vol. 16, no. 2, pp. 87-98. DOI: 10.1515/iclr-2016-0016.

\begin{abstract}
Summary: The paper presents novel data on international human rights in the Czech legal education. The importance of international human rights treaties and case-law of human rights bodies in the domestic practice gradually increases, therefore the students of Czech law schools should be familiar with the grounds of the sub-discipline, especially with the interpretative techniques used by international human rights bodies. The paper categorizes the approaches which the Czech law faculties employ as regards educating students in international human rights field and evaluates advantages and disadvantages of the approaches implemented by individual law schools. Finally, the paper identifies weak spots in Czech legal curricula and proposes some ideas for improvement.
\end{abstract}

Keywords: Human rights; legal education; Czech Republic; the European Convention on Human Rights; the European Court of Human Rights; international law; constitutional law; clinics; moot courts.

\section{Introduction}

The Western liberal order to which Czechoslovakia sought to belong after the November 1989 "Velvet Revolution" counts among its building blocks the concepts of human rights, rule of law and democracy. International organizations both on the universal (the United Nations) and regional level (e.g. the Council of Europe) have produced a number of human rights treaties and established mechanisms which should oversee the State's compliance with the ratified treaties. Even pre-1989 Czechoslovakia joined many international treaties, but similarly as other non-democratic illiberal states, without clear intention to fulfil their content, which was made possible either through the usually weak control mechanism of the treaties, or through the use of procedural reservations which domestically incapacitated the potentially effective international human

1 The paper has been written within the project „Mezinárodní lidskoprávní závazky České republiky: trendy praxe, prríčiny a důsledky" ("International Human Rights Obligations of the Czech Republic: Trends, Practice, Causes and Consequences" funded by the Grant Agency of the Czech Republic under the No. GA-1327956-S. 
rights regime. After the fall of the Eastern bloc, the newly democratizing countries subscribed to values which substantially differed from the previous set and gradually introduced mechanisms for free and fair election, and for safeguarding human rights, especially individual, and the rule of law.

Due to the abrupt change in the nature of political regime and accompanied values, the Czechoslovak (and then Czech) institutions were not fully prepared to absorb transformation, partially due to the lack of personnel with the mindset conforming to the newly introduced set of values and requirements. Lawyers belong among the backbone of the state administration, they are necessary both in production of laws and then in their authoritative application. The idea of human rights permeates law in modern European (or more widely, Western) countries, therefore the graduates of the law faculties should be familiar with the fundamentals of values which substantiate the whole political and legal orders. The content of these values is to a large extent influenced by the international human rights treaties and their supervisory bodies.

Our paper focuses on the education in international human rights in Czech law schools and seeks to uncover some common trends in the Czech legal academia and identify the main differences in approaches of the Czech law schools. We build our inferences on the data gained from the list of international human rights courses and their syllabi available on websites, or delivered by the schools upon our request. We discuss advantages and disadvantages of individual approaches and make recommendations, so that graduates of domestic law schools better conform to expectations of nowadays European "legal market".

\section{Importance of Education in International Human Rights}

As already mentioned above, the direct applicability of human rights has become an inevitable feature of all liberal democratic states, not excepting the post-communist countries, in the last few decades. This process developed from the assertion that the human rights stipulated in the national constitutions represented simple monologues of the legislator ${ }^{2}$ (i.e. "only" general principles and limits which the Parliament had set upon itself as rules for its future acts) to the concept of rights directly applicable on individuals in any judicial proceedings, or even in the relations between individuals.

Therefore, human rights represent almost an everyday part of lawyers' activities, irrespective of the particular subject of their interest and specialization. Although there are, of course, spheres of law in which the knowledge of human rights and the methods of their application and interpretation are employed more often or even regularly, one must admit that they ceased to be subjects of expert legal knowledge and penetrate even to the civil law disciplines.

2 WEYR, František. Československé právo ústavní. Prague: Melantrich, 1937, pp. 248. 
The human rights competency seems to be essential in all the spheres of legal work: from legislation, through clients' representation by attorneys, to adjudication at courts. As concerns the situation in the Czech Republic, any bill proposed by the Government must fulfil the test of human rights conformity that is conducted by the ministry presenting the bill and being responsible for the compliance of the bill with human rights. ${ }^{3}$ The true exercise of this rule is however very debatable: in most cases, the proposing ministry does not perform a careful test of conformity with human rights. Instead, it rather shortly and vaguely stipulates that the act does not contravene fundamental rights and freedoms without employing any methods that are used in the conformity tests (see later in the text). ${ }^{4}$ This example shows that even the lawyers employed by the state who are in the first line responsible for due implementation of human rights are not familiar with their relevance and impact.

The same scenario can be experienced at many proceedings before the ordinary courts: it happens quite often that a judge argues the human rights are determined and suitable for consideration only at higher courts proceedings, or even for the proceedings before constitutional courts or international human rights courts. ${ }^{5}$ These practical examples demonstrate the importance of human rights education, either at universities, or at other educational institutions responsible for professional training of lawyers (for example, in the Czech Republic it can be the Judicial Academy or seminars organised by the Czech Bar Association).

One could say that the expert knowledge is still based on the detailed familiarity with the content of all human rights treaties, the documents and the decisions of all the bodies applying the treaties etc., while the general legal knowledge rests in the orientation of lawyers at least in the sources of human rights, human rights databases and in the application of methods through which the human rights are applied and interpreted by relevant international bodies.

It seems to us that it is not necessary to put into the curriculum of legal education detailed courses on international human rights treaties; the courses that would combine practical skills with the general theory of human rights and the specific methods of their application and interpretation are rather needed. This good practice should start from teaching the students where they can find dif-

3 For details see KNĚŽÍNEK, Jan. Mezinárodní lidskoprávní závazky a jejich implementace v české legislativě. In POSPÍŠIL, Ivo, TY̌Č, Vladimír (eds.). Mezinárodní lidskoprávní závazky postkomunistických zemí:př́pady České republiky a Slovenska. Prague: Leges, 2016, pp. 138.

4 This assertion is very easy to verify: these short and vague stipulations create a part of the so-called explanatory report that is attached to every act passed by the Parliament.

5 See the particular experience of Martin Kopa in his review of the book Mezinárodní lidskoprávní závazky postkomunistických zemí: př́ípady České republiky a Slovenska. In KOPA, Martin. International Human Rights Obligations of Post-Communist Countries: the Cases of the Czech Republic and Slovakia. In ŠTURMA, Pavel (ed.). Czech Yearbook of Public and Private International Law. Prague: Czech Society of International Law, 2016, pp. 496. 
ferent sources of international human rights, what are the authoritative databases to be used and how to effectively work with these databases, including the methods of searching and undertaking research. Another part of the curricula should bring a more general and theoretical approach to the topic. Practically, it means introducing the students with the typology, generations or classification of human rights and the results that could derive from their different nature and character, and the methods of "optimization" between rights in conflict, rather than to present the students with the comprehensive catalogues of all the human rights stemming from the international treaties.

It requires at least to show the students that the application and interpretation of human rights have its specific aspects that differ from other legal disciplines. Methods of interpretation that are common in other legal fields such as the principle of "lex posterior derogat legi priori" or "lex specialis derogat legi generali" are replaced with different methods of thinking. For example, while interpreting mutually colliding rights and other principles, it is necessary to preserve the highest possible level of protection from both rights and principles using the methods of balancing. The students should get the information that there are different ways how to perform the balancing and that the particular method depends on the body applying human rights: there is a difference between the U.S. classification of rights that is connected with different tests (strict scrutiny, intermediate scrutiny and minimal scrutiny test - rational basis test), and many different models of proportionality tests used by international as well as national bodies worldwide. $^{6}$

This part of the curricula should be later complemented with a part devoted to the practical examples that would show the application of these general methods in the jurisprudence and case-law of international bodies and courts. It is even possible to train the students by employing the different methods of balancing while using the existing cases. This will teach students to think critically and analytically about the application of human rights which is more important than to memorize the human rights catalogues.

\section{International Human Rights Education in the Czech Republic ${ }^{7}$}

Even though human rights were one of the phenomena of the second half of the $20^{\text {th }}$ century in the Western liberal world, the teaching of human rights at law faculties in the newly born Czech Republic had to start in the early 1990s practi-

6 For details see BARAK, Aharon. Proportionality. Constitutional Rights and Their Limitations. Cambridge: Cambridge University Press, 2012, pp. 202-205 and 509 ff. or in a shorter version, dealing specifically with the Czech example see KOSA ̌, David. Kolize základních práv v judikatuře Ústavního soudu. Jurisprudence, 2008, XVII, No. 1, pp. 3-19.

7 This part of the paper partially draws on SMEKAL, Hubert, ŠIPULOVÁ, Katarína, POSPÍŠIL, Ivo, JANOVSKÝ, Jozef, KILIAN, Petr. Making Sense of Human Rights Commitments: A Study of Two Emerging European Democracies. Brno: Munipress, 2016. 
cally from scratch. As was already mentioned, the communist Czechoslovakia did not shy away from signing and ratifying human rights treaties. ${ }^{8}$ Similarly, human rights were not completely ignored by Czechoslovak law schools either, with the constitutional law textbooks usually devoting one chapter to them. However, the perception of human rights by socialist states differed significantly to how human rights were understood by the Western world. While liberal democratic states considered the individual to be at the centre of human rights, the Eastern bloc emphasized the role of the state and used human rights to promote its importance. ${ }^{9}$ Human dignity and freedom, which are cornerstones of the present Czech constitutional order, ${ }^{10}$ were of little significance in socialist constitutions. ${ }^{11}$

It follows that the academic staff at law schools in post-revolutionary Czechoslovakia had only limited experience with the human rights law as viewed and interpreted by liberal democratic countries. At the same time, there were basically no up-to-date human rights law publications in the Czech language. Indeed, foreign books were of little use because of the low level of students' knowledge of foreign languages (with the exception of Russian). These factors limited the possibilities for real progress in human rights education during the 1990s. ${ }^{12}$

As a result of a failed modernization of post-communist higher education, ${ }^{13}$ human rights law continued to play rather a marginal role in Czech legal education even at the beginning of the decade that followed. Although the fundamentals of human rights were taught in both constitutional law and international law courses, human rights issues were mainly left to philosophers, politicians, nonprofit organizations, and legal practitioners (especially constitutional courts) to deal with. Legal academics usually did not pay enough attention to human rights law. ${ }^{14}$

8 See also Šipulová, Katarína, JANOVSKÝ, Jozef, SMEKAL, Hubert. Mezinárodní lidskoprávní závazky České republiky a Slovenska. In POSPÍŠIL, Ivo, TÝČ, Vladimír (eds.). Mezinárodní lidskoprávní závazky postkomunistických zemí: př́pady České republiky a Slovenska. Prague: Leges, 2016, pp. 25.

9 SHAW, Malcolm N. International Law. Cambridge: Cambridge University Press, 2008, pp. 268.

10 BAROŠ, Jiří. Čl. 1. In WAGNEROVÁ Eliška et al. (eds). Listina základních práv a svobod. Komentár. Praha: Wolters Kluwer, 2012, pp. 60.

11 WAGNEROVÁ, Eliška. Základní práva. In BOBEK Michal et al. (eds). Komunistické právo $v$ Československu. Kapitoly z dějin bezpráví. Brno: Mezinárodní politologický ústav, Masarykova univerzita, 2009, pp. 346.

12 However, such a picture is not unknow also from social sciences - see KRPEC, Oldřich, OCELÍK, Petr, SMEKAL, Hubert. Narrowing the Divide. Perspectives on the Future of Mixed Methods Report from Central and Eastern Europe. Journal of Mixed Methods Research, 2016.

13 See TUCKER, Aviezer. Reproducing Incompetence: The Constitution of Czech Higher Education. East European Constitutional Review, 2000, vol. 9, No. 3, pp. 94-99.

14 MOLEK, Pavel. Právo na spravedlivý proces. Praha: Wolters Kluwer, 2012, pp. 13. 
Real progress can therefore be seen only towards the end of the first decade of the $21^{\text {st }}$ century as more human rights-related publications appeared, ${ }^{15}$ the faculties recruited young lecturers and lecturers with experience from abroad, and the domestic doctrine of human rights began to take shape thanks to, among other factors, the case law of the Constitutional Court and the European Court of Human Rights. Consequently, some schools have created compulsory courses devoted specifically to human rights, while others have expanded their offer of non-mandatory human rights courses and other activities such as legal clinics or moot courts.

Today, human rights law is a firm part of the curriculum at every Czech law school. However, the schools differ significantly in the number and variety of human rights courses offered. The most common approach is to introduce human rights to students through the constitutional law and public international law courses which are usually compulsory and are taught mainly during the first two years. These courses serve to explain the concept of human rights and their position in the national legal order and international law, respectively. More indepth study of human rights is then provided by specialized courses.

A notable exception to this concept is the law faculty in Olomouc which offers the first-year and the second-year students a compulsory course, entitled 'Fundamental Rights'. The law faculty in Brno also offers a compulsory human rights course ('Human Rights and Judiciary'), but it is designed for more mature students (usually fourth-year students). The idea behind compulsory courses in Olomouc and Brno, respectively, is therefore very different. The point of the 'Fundamental Rights' course can be seen in that it provides an initial introduction to human rights law, raises a certain level of human rights awareness among students and perhaps encourages them to choose more in-depth non-mandatory courses further down the road. Attending a human rights course so early in the curriculum should also lead the students to consider human rights questions in the rest of the courses as well. By contrast, Masaryk University considers it sufficient to introduce human rights only via a general constitutional law course. The students who take an interest in human rights may then attend non-mandatory courses while the rest will study human rights again in their fourth year. One of the advantages of this approach is that the older students should already have considerable knowledge of law which helps them to work with real human rights cases. Neither the law faculty in Prague, nor the law faculty in Pilsen offers a compulsory course oriented specifically on human rights, leaving it up to students' discretion whether or not they devote their time to human rights law at least via non-mandatory courses or other activities.

15 It should be mentioned, though, that already in 1990 Jiř́ Malenovský wrote the first edition of his book 'Mezinárodní právo veřejné' ('Public international law'). The book, in its latter editions, is still the leading international law textbook in the Czech Republic. See MALENOVSKÝ, Jiří. Mezinárodní právo veřejné - Obecná část a poměr k jiným právním systémům. $6^{\text {th }}$ ed. Brno: Doplněk, 2014. 
As to non-mandatory courses, the majority of Czech law schools ${ }^{16}$ offer a wide range of courses that are related to human rights law. These are often very practice-oriented and motivate the students not only to memorize but also to learn how to apply their knowledge. A great emphasis is given to the case law of the Czech Constitutional Court and the European Court of Human Rights and the students are often required to 'solve' a human rights case, or to write a mock petition to one of the aforementioned courts. This approach can be seen as a very positive change compared to how law was taught only a decade ago ${ }^{17}$ and moreover, is present across all four Czech law faculties.

The emphasis on the practical aspects of human rights law is further enhanced by other activities that are organized or co-organized by the respective schools. These include summer schools, ${ }^{18}$ legal clinics, ${ }^{19}$ internships at courts or in non-governmental organizations, ${ }^{20}$ and moot courts. As to the latter, the students may participate in various international moot courts, such as the European Human Rights Moot Court Competition ${ }^{21}$ or the Philip C. Jessup International Law Moot Court Competition. ${ }^{22}$ Moreover, the League of Human Rights ${ }^{23}$ organizes a national human rights moot court competition with the finals taking

16 The lowest number of human rights oriented courses is probably offered by the law faculty in Pilsen.

17 See BOBEK, Michal. O nereformovatelnosti studia práv v Čechách. Právní rozhledy, 2005, Vol. 13, No. 10, pp. 365-370; No. 12, pp. 446-451; No. 14, pp. 523-529; No. 16, pp. 601606.

18 An annual summer school on human rights is organized by the Law Faculty in Brno.

19 It is the faculty in Olomouc that is particularly active in this regard, organizing legal clinics dealing with social rights, discrimination law, refugee law, and medical law, as well as a specialized human rights clinic. In Brno, the students can attend legal clinics regarding medical law, international legal protection of children, refugee law, anti-discrimination law, and others. Building on a 15-year tradition, the Prague Law Faculty also offers practice-oriented courses in which students apply their skills and knowledge to real cases under the supervision of lawyers from non-governmental organizations or the office of the Public Defender of Rights

20 The students from Brno probably have a slight advantage in this area, given the fact that the Supreme Administrative Court, the Supreme Court, and the Constitutional Court, which are situated in Brno, have become increasingly open to offer internships lately. As part of these internships, the students often get the opportunity to work on a real case.

21 Particularly successful in this young competition has been the team from Prague, reaching the $7^{\text {th }}$ place in 2013 (the inaugural year of the competition) and making it to the final 8 again in 2016.

22 While the Jessup primarily focuses on general international law, it usually raises at least one human rights issue. During past years, the Czech Republic has usually been represented by one team in the international rounds of the competition. The success of Czech teams has been rather moderate, although in 2010, the team from Brno finished in the $13^{\text {th }}$ place in the written round of the global competition.

23 This non-profit organization organizes also other competitions and events focused on human rights. One of them is the 'Human Rights Dissertation', a competition for the best dissertation focused on human rights (the competition is not limited to law students). 
place at the Constitutional Court. The judges of the Supreme Court, the Supreme Administrative Court and the Constitutional Court are usually invited to judge the final rounds. However, it should be noted, that although participation in a moot court competition - and particularly if it is an international one - certainly enhances one's curriculum vitae, the interest in these competitions among the students is in fact rather low. Schools rarely motivate their students, ${ }^{24}$ or the faculty members, to take part in moot courts despite the fact that a success in the competition may raise the prestige of the school inasmuch as the media are interested in such events.

Indeed, the list of the courses and other activities offered to students do not tell the whole story. Of equal or even greater importance is the teaching staff. Without experienced and dedicated lecturers, there is not much difference between attending a course and reading a book at home. It is impossible to compare the respective teaching staffs and make a statement about the standing of individual faculties. That would require seeing each and every single one of the lecturers in action multiple times, and still it would be very difficult to evaluate staffs objectively. In general, though, the Czech law schools have benefited greatly from the possibilities the students and young lawyers have today to study or work abroad. The majority of young lecturers have had such experience during the past twenty years, and thus they have provided the schools with what had been so much missing during the communist era. It is not uncommon that faculty members have working experience from the highest national courts, or the European Court of Human Rights and other international institutions. Many of the law schools have also managed to attract various justices of the Constitutional Court (although not all of them necessarily teach human rights law), thereby providing the students direct contact with the 'real' human rights law as practiced among the highest human rights authorities. ${ }^{25}$

\section{Analysis of the Trends}

As we described above, human rights battled their way to the curricula of the Czech law schools only gradually. After the initial issues related to the lack of available and suitable lecturers and textbooks, competent personalities often with experience from abroad filled the places and publications in the field flourished. The initiative came from below; no pressure from above (e.g. from the Ministry of Justice, or Education) has been applied. On the other hand, the lack of coordination resulted in diversity in approaches in the international human rights education. Based on the aforementioned data from the four Czech law schools, we identified different approaches to the teaching of human rights,

24 Recently, at least, participation in a moot court has begun to be awarded with ECTS credits, something that just a few years earlier was not the rule.

25 For example, the Department of Constitutional Law and Political Science of the Faculty of Law of Masaryk University includes three Justices of the Constitutional Court (along with law clerks from the same court) and a judge of the Supreme Administrative Court. 
which are further analysed and evaluated. The discussed aspects include the issue of a mandatory subject on human rights, its timing (early, or later in the curriculum), substitution of a mandatory subject via constitutional and/or international law, special activities like legal clinics and moot courts, and Eurocentric (or even European Convention-centric) approach.

The Czech law schools differ in the basic fact regarding education in human rights: two schools (Brno and Olomouc) have specialized courses on this issue, while the other two (Pilsen and Prague) not. We have elaborated on the importance of human rights in previous sections - they count among fundamental values of Western political and legal systems, permeate their functioning, and are enshrined in constitutional texts. Moreover, international treaties and caselaw largely influence the domestic human rights practice. Thanks to the crosscutting characteristics of human rights, their reach is close to unlimited - almost every issue can be viewed also through the human rights perspective. ${ }^{26}$ The high importance of international human rights in nowadays European legal systems thus seems to be beyond doubt. It follows that graduates of (not only) Czech law schools should be familiar not only with readily useful practicalities like the texts of the treaties, case-law of international bodies and their interpretative techniques, but also with the most important theoretical concepts and "human rights approach" which informs interpretation of the bodies. It seems that understanding of this basis which provides sense for the practical superstructure requires a standalone course which would not be dominated by the international law, or constitutional law paradigm. It follows that a mandatory course on human rights is a preferable option from the perspective of the modern European legal curriculum.

The law schools in Brno and Olomouc both have a mandatory course on human rights, but approach it differently in the sense of its timing. While Palacký University in Olomouc places the course to the very first year of the legal education, Masaryk University in Brno waits until the late stage of the studies. Both approaches have their pros and cons and both present viable alternatives. Early exposure to the world of human rights raises the rights awareness and sensitivity freshly from the beginning of the university education and might encourage students to enrol in optional human rights courses later in the studies. Furthermore, it shall inform thinking of students also in other courses whose specific issues and questions could be seen in the additional layer of the human rights perspective. On the other hand, the mandatory human rights course in the later stage of legal education welcomes already more mature students with broader knowledge of law and with greater practical competences which enable them to work with real-life cases. Moreover, these advanced students have already been introduced

26 Compare for example the progressive encompassing of human rights by the European Union (then the European Communities) which have only slowly accepted them through the European Court of Justice as a part of the general principles in cases which are predominantly of economic nature and regard economic aspects of the European integration. 
to human rights via courses in constitutional, or international law. But unfortunately, they have lost the chance to absorb the human rights perspective early which has narrowed their way of looking at legal problems during their legal education. Additionally, with advancing stages of the studies and approaching expectations of entering the job market, the demand for practical skills increases and students are usually robbed of the pleasure of theoretical thinking. Thus, the ratio of advantages and disadvantages of inclusion of a human rights course in the early phase of legal studies, in our view, overweighs its later addition.

The law schools which do not have a mandatory human rights course compensate this deficit through courses on constitutional and international law. As discussed above, both these legal fields are dominated by their own perspectives, and human rights form only a part of their interest, therefore their coverage remains limited. Moreover, the specific human rights approach typically remains side-lined in such scenario. The issue becomes even more pressing in nowadays Europe which faces numerous intertwined crises (economic, inequality, migration, legitimacy, etc.) contributing to the observed phenomenon of democratic backsliding. ${ }^{27}$ If the support for advancement of human society forms part of the mission of universities, then inspiring lawyers - as a future backbone and elite of the society - in building respect for human rights shall form one of priorities of legal education. When a student does not take any optional course, it leaves them only with basic knowledge of constitutional and international law without necessarily paying much attention to human rights, which is clearly a suboptimal scenario. Introducing students to human rights through an early course on constitutional law remains a preferable option to the introduction through the course on international law, because constitutional law departments have typically attracted strong cadres shortly after the November 1989 Velvet Revolution, while positions in international law departments have been in lesser demand, also due to initial incompetence in foreign languages. Furthermore, constitutional law firmly incorporates human rights in their theoretical apparatus and bind the international norms with domestic practice.

All four Czech law schools have established promising opportunities for students interested in human rights. All of them offer a series of optional courses which cover different agendas. Moreover, various non-traditional additions to the classical legal education are on the rise - heretofore in the Czech legal education unknown activities such as legal clinics, summer schools and moot courts flourish. ${ }^{28}$ Taken together with quite lively local non-governmental organiza-

27 See e.g. the debate on the democratic backsliding in the EU - special section in the Journal of European Public Policy introduced by Kelemen, R. Daniel, Blauberger, Michael. Introducing the debate: European Union safeguards against member states' democratic backsliding. Journal of European Public Policy, 2016.

28 Although moot courts could receive even more attention, because the international competition seems to be still beyond reach. But it seems that incentives both for students and their coaches are not high enough to attract e.g. for Jessup International Law Moot Court 
tions scene, then students interested in human rights both theoretically and practically have enough chances for personal fulfilment.

The last item discussed in this section concerns again a common trend at all Czech law schools - a strongly Eurocentric approach with a dominant focus on the European Convention on Human Rights system. In the first half of 1990s, the International Covenant on Civil and Political Rights and the jurisprudence of its Human Rights Committee received some attention, but it has been since then replaced with the case-law of the European Court of Human Rights whose judgments receive much more publicity and the most important of them are summarized in Czech. Moreover, several publications on the European Convention system appeared, especially the comprehensive commentary on the European Convention which has successfully hegemonized the field. ${ }^{29}$ The European Convention centred approach means that the activities of other bodies of the Council of Europe remain neglected which holds even more for the United Nations human rights regimes, let alone for other regional systems of human rights protection which leaves students close to untouched with the Inter-American or African systems. Such an educational reduction seems unfortunate, yet understandable. The European Court of Human Rights is considered the most effective court, it has a long tradition and an extensive case-law, therefore many domestic problems have been already discussed by the Strasbourg Court whose case-law is readily available, moreover accompanied by useful downloadable handbooks summarizing case-law on particular rights issued by the Council of Europe. Moreover, with the limited positions available at the Czech Law Schools, it would require Herculean efforts from the lecturers to follow not only domestic and international case-law, but also outputs of other treaty bodies and courts from different continents.

\section{Conclusion and Recommendations}

The situation in international human rights education at Czech law schools has improved considerably over the last few years, especially with lecturers returning back home with diplomas from foreign universities and with working experience from international institutions. The Czech law schools already offer various human rights courses. These cover both national and international mechanisms of human rights protection, as well as both the theory and practice of human rights. There exist also growing numbers of possibilities for the students to apply and test their skills and knowledge. The emphasis on practical aspects can be seen in the evaluation methods used in many human rights courses: as a part of the final examination, students are typically required to dem-

which typically involves a strong human rights component teams from all four Czech law schools.

29 KMEC, Jiř́, KOSAŘ, David, KRATOCHVÍL, Jan, BOBEK, Michal. Evropská úmluva o lidských právech. Komentár. Praha: C.H. Beck, 2012. 
onstrate their ability to apply the human rights law in particular real life cases by writing a simulated constitutional complaint or judgement. Furthermore, the Czech law faculties have introduced and help co-organize a wide range of activities focused on human rights (such as legal clinics or moot courts), thereby providing hands-on legal experience to their students. Finally, important roles are played by high courts and non-governmental organizations, which are increasingly open to offering various internships for law students. All these opportunities make human rights law appealing for students and enhance the chances that a higher number of them will focus on human rights during their studies.

Admittingly, there still remains a room for improvement. The Czech education in international human rights seems to suffer from a lack of coordination (although first steps in this direction have been taken at least in Brno and Olomouc). Individual courses exist; however, the overall situation does not create an impression of a result of a well-thought plan with a bigger picture in mind, but rather a result of incremental piece-meal development. More communication among various entities dealing with international human rights shall occur, so that efforts are not doubled e.g. in a course on the European Convention system and in a regular criminal law course.

Finally, given a rather high number of law-school students and a limited amount of time that could be devoted to each area of law, it is probably beyond the possibilities of any school to assure that each and every of its graduates have an excellent knowledge of human rights law. The inclusion of a compulsory human rights oriented course can certainly help to increase the overall knowledge of the students in this area. However, if the student is truly interested in human rights law, it is up to them to actively look for other opportunities that their school offers, whether it is a non-mandatory course, legal clinic, moot court or an internship. At the majority of Czech law schools, these active students can get a solid foundation if they seek a career in the human rights field. On the other hand, the knowledge of human rights law of the disinterested alumni will be rather limited. 